17 Rein CR. Diagnostic aids in mass-treatment campaigns against yaws. In: First international symposium on yaws control. Geneva: World Health Organisation, 1953:245-54. (Monograph series no 15 .)

18 Levitan S, Rodriguez C, Jacobs JC. The treatment of infectious yaws with one injection of penicillin. In: First international symposium on yaws control. Geneva: World Health Organisation, 1953:55-75. (Monograph series no 15.)

\section{Granulocytopenia and septicaemia}

Patients with severe granulocytopenia easily acquire Gramnegative septicaemia. This complication is justifiably feared: apart from fever the physical signs are few, but if it is not treated early and appropriately it may rapidly progress to circulatory collapse and death.

Prevention might seem the best policy, but isolation and reversed barrier nursing have little to offer, since the organisms responsible are almost invariably endogenous. Sterilisation of the bowel with non-absorbable antibiotics probably delays the onset of infection and is widely practised, ${ }^{1}$ but even so most patients with severe granulocytopenia eventually become infected.

These infections progress so fast that there is no time to wait for results of bacteriological investigations, and treatment with antibiotics should be started as soon as specimens have been taken. Indeed many units dealing with patients with granulocytopenia recommend treatment of every fever of $38^{\circ} \mathrm{C}$ (or higher) that persists for more than two hours. Such a policy means that some transfusion or drug reactions will be treated inappropriately with antibiotics, which should be stopped as soon as infection is excluded.

The choice of antibiotics is empirical but not blind. The likely organisms are Escherichia coli, Klebsiella spp, or Pseudomonas aeruginosa. In patients with persistent granulocytopenia recovery is almost twice as likely if the organism is susceptible to two of the antibiotics administered rather than only one. ${ }^{2}$ Probably the most favoured regimen is gentamicin and carbenicillin. A system of bacteriological surveillance which provides information about the patients' own flora and local drug resistances will be a valuable guide to the use of the newer aminoglycosides tobramycin and amikacin. Cephalothin is indicated if infection with Klebsiella is suspected. ${ }^{3}$

One of the most important factors determining the chances of recovery is a spontaneous rise in the granulocyte count. Love $e t a l^{2}$ found a recovery rate of $93 \%$ in patients whose granulocyte counts rose by as little as $100 \times 10^{6} / 1$ over the first 14 days of treatment compared with only $55 \%$ in those in whom the count remained unchanged. These statistics suggest that white-cell transfusions might be life saving. Should white cells be as freely available as red cells and platelets? The answer is logistic. The daily turnover of granulocytes in a non-infected adult is $1.2 \times 10^{11}$, with the mature neutrophil spending on average six hours in the circulation. ${ }^{4}$ During infections the turnover is greatly increased. Even to replace the normal daily requirement would mean transfusing the granulocytes from 80 units of fresh donor blood. Given these figures, white-cell transfusions might be expected to have little practical value. Nevertheless, despite earlier controversy, ${ }^{5}$ controlled trials have shown that daily infusions of $2 \times 10^{10}$ granulocytes are effective in controlling Gram-negative septicaemias in patients with initial granulocyte counts of less than $500 \times 10^{6} / 1 .^{6-8}$
Sufficient granulocytes can be obtained from a donor in about four hours using filtration leucapheresis or continuousflow centrifugation. Discontinuous-flow centrifugation is somewhat less efficient. Granulocytes from any of these sources are equally effective, but those produced by filtration cause more transfusion reactions. ${ }^{9}$ To make granulocyte infusions available for every infection in which they might be beneficial would require a vast investment in both machinery and manpower. Furthermore, granulocytes are highly antigenic and share antigens with platelets. One controlled trial of prophylactic granulocyte transfusions in acute non-lymphocytic leukaemia showed no benefit over controls and a high incidence of alloimmunisation producing resistance to platelet transfusions. ${ }^{10}$ In theory such reactions could be avoided by the use of granulocytes matched for HLA compatibility, but this would create even greater logistic problems, far beyond present resources.

In practice most units, and especially those with the most experience of granulocyte transfusions, find that they are needed only rarely. They can be beneficial in patients with prolonged aplasia and inadequate response to initial antibiotics, and these patients should be identified as soon as possible; granulocyte transfusions are not necessary for the majority of patients, whose marrows may soon be expected to show signs of recovery.

1 Storring RA, Jameson B, McElwain TJ, Wiltshaw E, Spiers ASD, Gaya H Oral non-absorbed antibiotics prevent infection in acute non-lymphoblastic leukaemia. Lancet 1977 ;ii:837-40.

2 Love LJ, Schimpff SC, Schiffer CA, Wiernik PH. Improved prognosis for granulocytopenic patients with Gram-negative bacteremia. $A m \mathcal{F}$ Med 1980;68:643-8.

${ }^{3}$ Schimpff SC. Therapy of infection in patients with granulocytopenia. Med Clin North Am 1977;61:1101-18.

4 Athens JW, Haab OP, Raab SO, et al. Leukokinetic studies. IV. The total blood, circulating and marginal granulocyte turnover rate in normal subjects. F Clin Invest 1961;40:989-95.

5 Fortuny IE, Bloomfield CD, Hadlock DC, Goldman A, Kennedy BJ, McCullough JJ. Granulocyte transfusion: a controlled study in patients with acute nonlymphocytic leukaemia. Transfusion 1975;15:548-58.

6 Herzig RH, Herzig GP, Graw RG, Bull MI, Ray KK. Successful granulocyte transfusion therapy for Gram-negative septicemia. A prospectively randomized controlled study. $N$ Engl f Med 1977;296:701-5.

7 Alavi JB, Root RK, Djerassi I, et al. A randomized clinical trial of granulocyte transfusions for infection in acute leukaemia. $N$ Engl $\mathcal{f}$ Med 1977;296:706-11

8 Vogler WR, Winton EF. A controlled study of the efficacy of granulocyte transfusions in patients with neutropenia. Am $\mathcal{F}$ Med 1977;63:548-55.

9 Aisner J, Schiffer CA, Wiernik PH. Granulocyte transfusions: evaluation of factors influencing results and a comparison of filtration and intermittent centrifugation leukapheresis. Br $\mathcal{F}$ Haematol 1978;38:121-9.

10 Schiffer CA, Aisner J, Daly PA, Schimpff SC, Wiernik PH. Alloimmunization following prophylactic granulocyte transfusion. Blood 1979;54: 766-74.

\section{Pancreatic transplantation}

Treatment of insulin-dependent diabetes is meant not only to save life but also to achieve the best possible "control" of the blood glucose. Even with the best modern insulin regimens and new techniques of monitoring diabetic control, however, considerable fluctuations still occur in blood glucose concentrations. Better results can be obtained with continuous subcutaneous infusion of insulin, ${ }^{1}$ but both this technique and the use of the large and expensive artificial pancreas are still experimental. In theory, at least, the most effective solution to these problems should be pancreatic transplantation -last reviewed in 1976. ${ }^{2}$ Now a recent conference in California has been reported in a supplement of Diabetes. ${ }^{3}$ 
Human transplantation of a pancreas was first undertaken in the United States in 1966, when a 28-year-old woman received a pancreas and a kidney at the same time. ${ }^{4}$ She died just over two months later. Since then probably fewer than 100 pancreatic transplantations have been performed, generally without success and with a high mortality. Only very few have functioned for over one year ${ }^{5}$ and only one for over four years. ${ }^{6}$ The chief problems have been rejection of the transplant and the disposal of pancreatic exocrine secretions. Ingenious technical ideas have not always been successful: techniques to ligate the duct ${ }^{5}$ and inject the duct ${ }^{7}$ have failed, while drainage of secretions to the small intestine, abdominal wall, ${ }^{8}$ peritoneal cavity, ${ }^{5}$ or ureter $^{9}$ have also been tried.

These failures of transplantation of the whole pancreas have led to extensive studies of transplanting the islets instead.$^{10}$ In animals diabetes can be reversed by this technique, but in man it usually fails because of rapid rejection. Furthermore, lack of sufficient islet tissue has usually meant that the grafts have had little if any measurable function. Tissue culture of the islets has been used ${ }^{10}$ in an attempt to increase the yield of islet tissue, and another approach has been the use of neonatal and fetal pancreas with or without culture. ${ }^{1112}$ All sorts of attempts have been made to overcome the immunological problems, ${ }^{13} 14$ but the need for immunosuppression places a severe limitation on the indications for human pancreatic transplantation. Indeed, if it is to be attempted at all, it should be undertaken only in patients already receiving immunosuppressive drugs, and most reported operations have been performed either simultaneously with or after renal transplantation. Pancreatic transplantation performed for "hyperlabile" diabetes or diabetic complications without uraemia $^{8}$ cannot be justified.

Though morbidity and mortality are high, whole-organ transplantation has proved to be more successful functionally than attempts at islet transplantation. Islet tissue, whether taken from human adult pancreas or fetal pancreas (and whether given intraperitoneally, intraportally, or intramuscularly), has failed to reduce the need for insulin. ${ }^{1516}$ Nevertheless, patients treated in this way have not been harmed, and in some instances measurement of C-peptide has suggested that some islet function is present. Apparently successful autotransplantation of islets has been reported after pancreatectomy was performed for chronic pancreatitis. ${ }^{15}$

Why attempt pancreatic transplantation at all? Unlike other organ transplants it does not save life, and whole-organ transplantation is still hazardous. Its justification requires not only the development of radically new methods of immunosuppression, together with improvements in the harvesting of islets, but also clear evidence that it is really better than conventional treatment with insulin. Nearly all diabetic patients needing renal transplantation have advanced complications, chiefly retinopathy and vascular disease, and there is little hope that these major structural abnormalities can be reversed. Most experience in human pancreatic trans- plantation comes from Minneapolis, where Goetz has suggested criteria by which to judge its efficacy in preventing or reversing long-term complications. ${ }^{17}$ These include prospective biopsy examination of the transplanted kidney to see whether the lesions which develop in diabetes ${ }^{18}$ can be prevented, together with electrophysiological studies of neuropathy and measurements of muscle basement membranes. In diabetic rats some changes in the glomeruli can be reversed and proteinuria decreased by islet transplantation ${ }^{1920}$ _encouraging results but insufficient to warrant human transplantation.

1 Pickup JC, Keen H, Viberti GC, et al. Continuous subcutaneous insulin infusion in the treatment of diabetes mellitus. Diabetes Care 1980;3 290-300.

2 Matas AJ, Sutherland DER, Najarian IS. Current status of islet and pancreas transplantation in diabetes. Diabetes $1976 ; 25: 785-95$.

${ }^{3}$ Brown J, ed. Proceedings of a conference on pancreas transplantation. Diabetes $1980 ; 29$, suppl $1: 1-125$.

4 Kelly WD, Lillehei RG, Merkel FK, Idezuki Y, Goetz FC. Allotransplantation of the pancreas and duodenum along with the kidney in diabetic nephropathy. Surgery $1967 ; 61: 827-37$.

5 Sutherland DER, Goetz FC, Najarian JS. Clinical segmental pancreas transplantation without duct anastomosis in diabetic renal allograft recipients. Diabetes $1980 ; 29$, suppl 1:10-8.

6 Gliedman ML, Tellis VA, Soberman R, Rifkin H, Veith FJ. Long-term effects of pancreatic transplant function in patients with advanced juvenile onset diabetes mellitus. Diabetes Care 1978;1:1-9.

7 Traeger J, Dubernard JM, Touraine JL, et al. Pancreatic transplantation in man: a new method of pancreas preparation and results on diabetes correction. Transplant Proc 1979;11:331-5.

${ }^{8}$ Groth CG, Lundgren G, Gunnarsson R, Arner P, Berg B, Östman J. Segmental pancreatic transplantation with duct ligation or drainage to a jejunal Roux-en-Y loop in nonuremic diabetic patients. Diabetes 1980;29, suppl 1:3-9.

${ }^{9}$ Gliedman ML, Tellis V, Soberman R, Rifkin H, Freed SZ, Veith FJ. The clinical use of steroids in pancreatic transplantation. Transplant Proc 1975;7:93-8.

${ }^{10}$ Reemtsma K, Weber CJ, Pi-Sunyer FX, Lerner RL, Hardy MA. Alternatives in pancreatic islet transplantation: tissue culture studies. Diabetes 1980;29, suppl 1:45-51.

11 Usadel KH, Schwedes U, Bastert G, et al. Transplantation of human fetal pancreas: experience in thymusaplastic mice and rats and in a diabetic patient. Diabetes $1980 ; 29$, suppl $1: 74-9$.

12 Maitland JE, Parry DG, Turtle JR. Perifusion and culture of human fetal pancreas. Diabetes $1980 ; 29$, suppl 1:57-63.

13 Barker CF, Naji A, Silvers WK. Immunologic problems in islet transplantation. Diabetes $1980 ; 29$, suppl 1:86-92.

14 McMaster P, Procyshyn A, Calne RY, Valdes R, Rolles K, Smith DJ. Prolongation of canine pancreas allograft survival with cyclosporin $A$ : preliminary report. $\mathrm{Br}$ Med $\mathcal{F} 1980 ; 280: 444-5$.

15 Sutherland DER, Matas AJ, Goetz FC, Najarian JS. Transplantation of dispersed pancreatic islet tissue in humans: autografts and allografts. Diabetes $1980 ; 29$, suppl 1:31-44.

16 Groth CG, Andersson A, Björken C, et al. Transplantation of fetal pancreatic microfragments via the portal vein to a diabetic patient. Diabetes $1980 ; 29$, suppl $1: 80-3$.

17 Goetz FC. Evaluating the benefits of human islet transplantation. Diabetes $1980 ; 29$, suppl 1:52-5.

18 Mauer SM, Barbosa J, Vernier RL, et al. Development of diabetic vascular lesions in normal kidneys transplanted into patients with diabetes mellitus. $N$ Engl f Med 1976;295:916-20.

${ }^{19}$ Mauer SM, Steffes MW, Sutherland DER, Najarian JS, Michael AF, Brown DM. Studies of the rate of regression of the glomerular lesions in diabetic rats treated with pancreatic islet transplantation. Diabetes $1975 ; 24: 280-5$.

${ }^{20}$ Mauer SM, Brown DM, Matas AJ, Steffes MW. Effects of pancreatic islet transplantation on the increased urinary albumin excretion rates in intact and uninephrectomized rats with diabetes mellitus. Diabetes $1978 ; 27: 959-64$. 